\title{
Pulmonary arteriovenous malformation and Ebstein's anomaly in a patient: a rare combination
}

\author{
Syed Basharath Mehdi, Salem Madi
}

Respiratory Department, Wrightington Wigan and Leigh NHS Foundation trust, Wigan, Lancashire, UK

\section{Correspondence to} Dr Syed Basharath Mehdi, syedbasharath@yahoo.com

Accepted 2 November 2014
CrossMark

To cite: Mehdi SB, Madi S. BMJ Case Rep Published online: [please include Day Month Year] doi:10.1136/ bcr-2014-207863

\section{DESCRIPTION}

We present a 58-year-old woman with a history of atrial fibrillation, hypothyroidism, iron-deficient anaemia and multiple deep vein thrombosis (DVT). She never smoked and had no allergies. Her medications included thyroxine, ferrous sulfate, bisoprolol, digoxin and apixaban.

She presented with epistaxis while on warfarin for her DVT and was treated conservatively. She was investigated for iron-deficiency anaemia with endoscopic procedure which revealed multiple angiodysplastic lesions in duodenum and descending colon.

She was seen in chest outpatient clinic with leftsided chest pain which was a dull, constant ache, worse when lying on the left side associated with breathlessness. Transthoracic echocardiogram (figure 1) revealed severely impaired systolic left ventricular function with dilated left atrium. Right heart was dilated with Ebstein's anomaly of the tricuspid valve. ${ }^{1}{ }^{2}$ A CT pulmonary angiogram (figure 2) showed an arteriovenous malformation in the left lower lobe and middle lobe. ${ }^{3}$

She was managed conservatively and she is clinically stable.

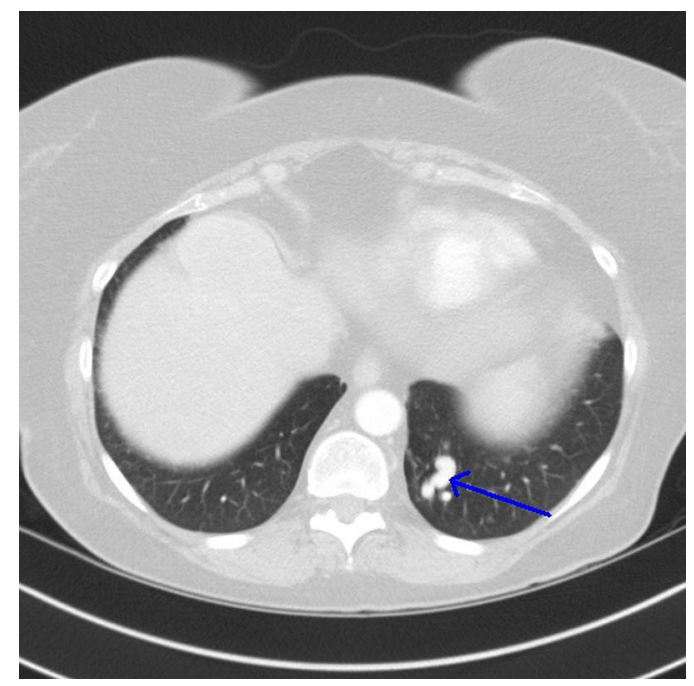

Figure 2 CT image showing serpiginous lesion consistent with pulmonary arteriovenous malformation.

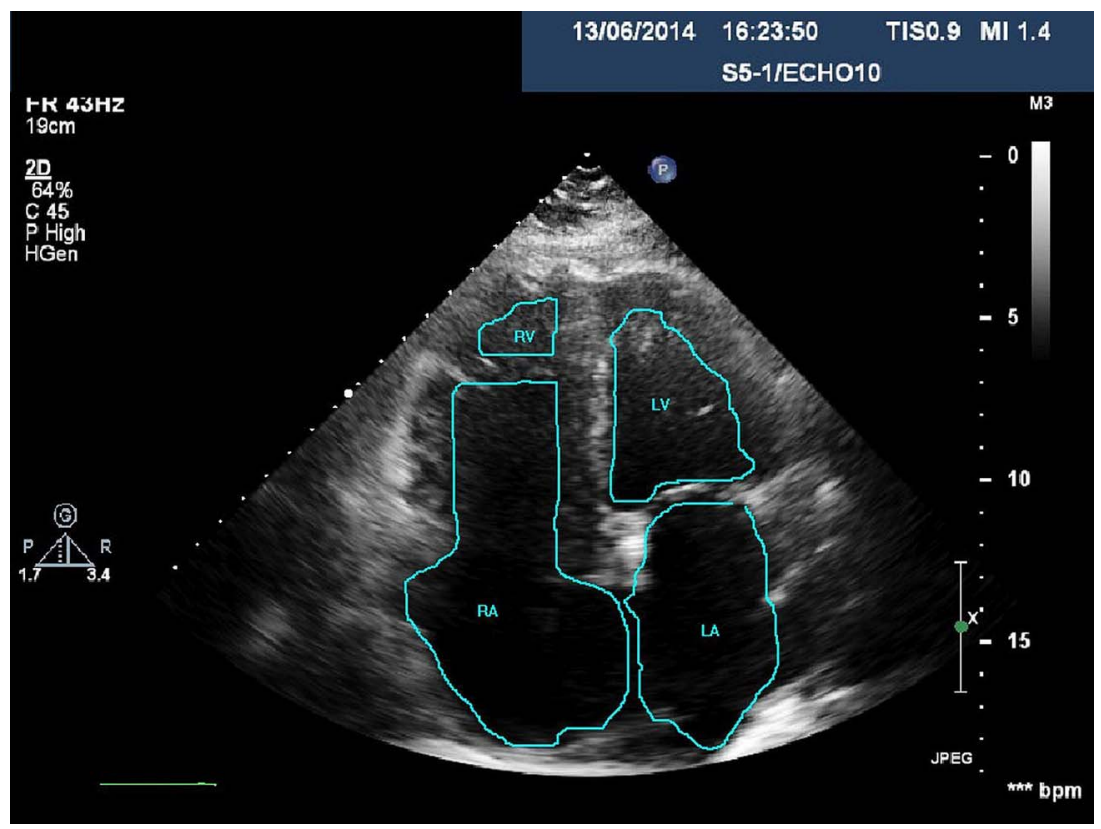

Figure 1 ECHO image showing dilation of the RA (RV, right ventricle; LV, left ventricle; RA, right atrium; LA, left atrium). 


\section{Learning points}

Pulmonary arteriovenous malformation and Ebstein's anomaly occurring in the same patient is a rare condition.

- Management approach is difficult because of its rarity, however in our patient conservative approach was adopted.

- Further genetic and embryonic studies are needed to identify a possible relationship of the two medical conditions.
Competing interests None.

Patient consent Obtained.

Provenance and peer review Not commissioned; externally peer reviewed.

\section{REFERENCES}

1 Park K, Kim C, Lim DS, et al. A case of a pulmonary arteriovenous malformation with Ebstein's anomaly. Korean Circ J 2010;40:684-6.

2 Attenhofer Jost $\mathrm{CH}$, Connolly HM, Dearani JA, et al. Ebstein's anomaly. Circulation 2007; 115:277-85.

3 Pick A, Deschamps C, Stanson AW. Pulmonary arteriovenous fistula: presentation, diagnosis, and treatment. World J Surg 1999;23:1118-22.

Copyright 2014 BMJ Publishing Group. All rights reserved. For permission to reuse any of this content visit http://group.bmj.com/group/rights-licensing/permissions.

BMJ Case Report Fellows may re-use this article for personal use and teaching without any further permission.

Become a Fellow of BMJ Case Reports today and you can:

- Submit as many cases as you like

- Enjoy fast sympathetic peer review and rapid publication of accepted articles

- Access all the published articles

- Re-use any of the published material for personal use and teaching without further permission

For information on Institutional Fellowships contact consortiasales@bmjgroup.com

Visit casereports.bmj.com for more articles like this and to become a Fellow 